\title{
Ordovician chitinous hydroids from Hudson Strait, District of Franklin, Northwest Territories
}

\author{
Merrell A. Miller \\ Amoco Production Company, P.O. Box 3385, Tulsa, Oklahoma 74102, U.S.A. \\ and \\ Graham L. Williams \\ Atlantic Geoscience Centre, Geological Survey of Canada, Bedford Institute of Oceanography, \\ P.O. Box 1006, Dartmouth, Nova Scotia B2Y 4A2, Canada
}

Date Received March 26, 1991

Date Accepted July 11, 1991

\begin{abstract}
Chitinous hydroids are documented for the first time from the Upper Ordovician of Eastern Canada, and for the fourth time from North American rocks. One hydrosome branch segment is provisionally attributed to Rhabdohydra Kozlowski. The excellent three dimensional preservation shows the periderm is layered and vesiculate. Periderm thinning, present in Recent chitinous hydroids, is also noted for Ordovician hydroids.
\end{abstract}

\begin{abstract}
Une première signalisation, d'hydroïdes chitineuses dans l'Ordovicien supérieur de l'Est du Canada vient s'ajouter aux trois documents déjà issus de roches nord-américaines. Un segment de rameau hydrosomal est rapporté avec réserve au genre Rhabdohydra Kozlowski. Une excellente conservation dans ses trois dimensions démontre que le périderme est vésiculeux et constitué de plusieurs couches. L'amincissement du périderme, phénomène connu des hydroïdes chitineuses actuelles, se manifeste aussi chez les hydroïdes ordoviciennes.
\end{abstract}

[Traduit par le journal]

\section{INTRODUCTION}

Two specimens of chitinous hydroids occur in a chitinozoan preparation from Ordovician bedrock, encountered in a shallow core hole from Hudson Strait, District of Franklin, Northwest Territories. The well preserved material represents only the fourth record of chitinous hydroids in North American rocks; the other occurrences are in the Ordovician Viola Group of southern Oklahoma (Taugourdeau, 1965), the Upper Ordovician Dillsboro Formation of Indiana (Miller, 1976), and the Upper Silurian Read Bay Formation of Cornwallis Island (McGregor and Narbonne, 1978).

The core was one of several drilled from the research vessel CSS Hudson, during a bedrock and surficial sediment sampling and seismic survey (see MacLean et al., 1986, for details). Some of the cores have yielded abundant chitinozoans and acritarchs (Miller and Williams, 1987, 1988).

Station 78, from which the sample containing chitinous hydroids was obtained, is located in northwest Hudson Strait (Fig. 1). This sample is a tan, slightly argillaceous, sparsely fossiliferous lime mudstone. Chitinozoans and acritarchs were recovered from about 59 grams, using the procedures outlined in Miller and Williams (1988). The palynomorph assemblages indicate a late Ordovician (Caradoc-Ashgill) age for the Station 78 sample and most of the Hudson Strait cores (Miller and Williams, 1987).

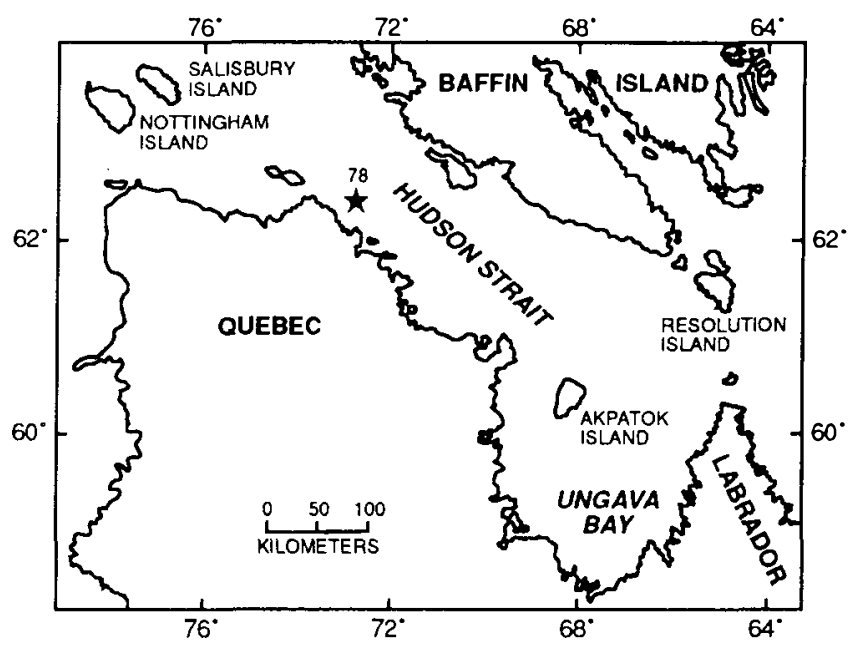

Fig. 1. Map of Hudson Strait showing the location(*) of Station 78 drilled by the BIO submersible drill during CSS Hudson cruise 85 027. Map adapted from MacLean et al. (1986).

\section{Chitinous Hydroids}

Chitinous hydroids have been reported from the Cambrian of Australia (Chapman and Thomas, 1936); the Cambrian and Ordovician of Tasmania (Quilty, 1971); the Ordovician of Greenland (Frykman, 1979); the Early Ordovician 
of Öland, Sweden (Skevington, 1965; Eisenack, 1976); the Silurian of Gotland, Sweden (Laufeld, 1979); and the Silurian of England (Eisenack, 1977, 1978). They also occur in glacial erratics of Ordovician and Silurian age from northem Europe (Eisenack, 1932, 1934, 1968, 1971; Kozlowski, 1959). A specimen figured in Eisenack (1955) as Chitinröhrchen (pl. 4 , fig. 15) may represent a chitinous hydroid. Occurrences in North American localities were listed above.

Although Laufeld (1979) stated that chitinous hydroids are common in Phanerozoic shelf sediments, he also noted that they have received little attention. Most reported occurrences are ancillary to either chitinozoan or graptolite studies.

The two specimens of chitinous hydroids recovered from Station 78 are three dimensionally preserved and thermally unaltered (Fig. 2). Both are short segments of erect, cylindrical hydrosome branches and have attached thecae.

The larger specimen (see Fig. 2A-E) is $2.5 \mathrm{~mm}$ long and $0.1 \mathrm{~mm}$ in diameter. In this short segment of hydrosome branch, the periderm thins from 20 microns to three microns, and the microstructure of the periderm also changes. The thicker portion of the wall, here presumed to be proximal, shows a vesicular structure in which subspherical vesicles are encased in periderm (Fig. 2D). The distal end of the hydrosome branch is composed of more than one wall layer (Fig. 2E). Our assumption that the thicker periderm occurs proximally is based on Kozlowski's (1959) observations that fossil chitinous hydroid periderm thins progressively from the hydrorhiza to the margin of the hydrosome. Additionally, Hyman (1940) reported that, in Recent hydroids with chitinous periderm, chitin was added successively to the periderm as the hydrosome grew.

Three simple thecae are present on this larger segment of hydrosome branch and are $0.5 \mathrm{~mm}$ and $0.6 \mathrm{~mm}$ apart (Fig. 2AC). The thecae are $0.1 \mathrm{~mm}$ to $0.11 \mathrm{~mm}$ long and $0.3 \mathrm{~mm}$ in diameter. They are cylindrical, recurved at their bases and attached to indentations in the hydrosome branch. They are either subparallel to the branch or directed away from it at an acute angle. The thecae are oriented unidirectionally, their axes forming an acute angle with the axis of the hydrosome branch. However, the thecal openings are directed towards the proximal rather than the distal end of the hydrosome segment. This pendant orientation of thecae may reflect primary growth or a necessary modification of thecal positioning due to hydrosome growth.

The thecal openings are entire and do not appear to have resulted from breakage (Fig. 2C). Hyman (1940) described cylindrical hydrothecae with entire openings in Recent hydroids. Two wall layers are apparently present in the thecae shown in Figure 2B. The periderms of both the thecae and the hydrosome are smooth and show evidence of minor crystal imprinting.

A porate diaphragm of undetermined thickness (Fig. 2D) is present in the proximal end of the branch illustrated in Figure 2A. The diaphragm has a dense laminar microstructure distinctly different from that of the adjacent periderm (Fig. 2D). The diaphragm is apparently separated from the smooth inner wall of the periderm, but the exact relationship between the two features is difficult to determine because of breakage. The diameter of the diaphragm pore is 23 microns. Kozlowski (1959) reported the presence of diaphragms at the bases of some hydrosome branches; perhaps this is the same type of structure that he described.

This specimen is comparable in size and type of thecae to a specimen considered to be an abnormal branch of $R$ habdohydra tridens Kozlowski by Kozlowski (1959, p. 238, fig. 14F). He indicated that the isolated theca are attached directly to a branch without the typical spatuliform processes present on Rhabdohydra tridens. Skevington (1965) considered simple thecae of the type described by Kozlowski to be the hooked peduncles of goniothecae Formae $A$ and $C$ (Kozlowski, 1959). Based on the theca illustrated in Figure $2 \mathrm{C}$, Skevington's interpretation seems unlikely for our specimen. The apertural opening is entire and shows no indication of damage that would be present where a goniotheca is broken off. Also, no isolated goniothecae were present in the sample from Station 78. We cannot determine if the specimen is a teratological specimen of $R$ habdohydra, as speculated by Kozlowski (1959) for his material, an ontogenic stage, or a different species. However, the entire apertural openings of the specimen illustrated in Figure $2 \mathrm{~A}$ indicate that they are simple thecae and not peduncles of missing gonothecae.

The second hydrozoan segment (Fig. 2F, G) is shorter than the first and has a single theca. The distal part of this theca is obviously broken. The attachment of the theca to the hydrosome branch is different from that of the specimen described above. The hydrosome branch is $1.2 \mathrm{~mm}$ long and $0.07 \mathrm{~mm}$ in diameter and distinctly thickened at the attachment point (Fig. 2F). The theca is $0.3 \mathrm{~mm}$ in diameter. The periderm is smooth except in the highly wrinkled, thecal attachment area (Fig. 2G).

Although the specimens illustrated here are fragmentary, they are well preserved and show details of the hydrosome branches and thecae as well as previously unrecorded wall structure. The observations do not elucidate hydrosome shape; however, they are useful in understanding the micromorphology of chitinous hydroids.

\section{ACKNOWLEDGEMENTS}

A study of the microfossils from the 85-027 cruise bedrock samples was initiated during G.L. Williams' change of work station at Amoco Production Company Research Center, Tulsa, December 1986 to August 1987. The two reviewers, D.G. McGregor (Geological Survey of Canada, Ottawa) and S.M. Bergström (Ohio State University, Columbus), raised several issues and did an excellent job of pointing out inconsistencies. We benefited considerably from their input. A.R. Ormiston (Amoco Research, Tulsa), G.D. Wood (Amoco Production, Houston), and R.A. Fensome (Geological Survey of Canada, Dartmouth) critically read this manuscript; their suggestions are greatly appreciated. S.C. Finney (California State University, Long Beach) graciously provided information on graptolites and hydrozoans. We thank 

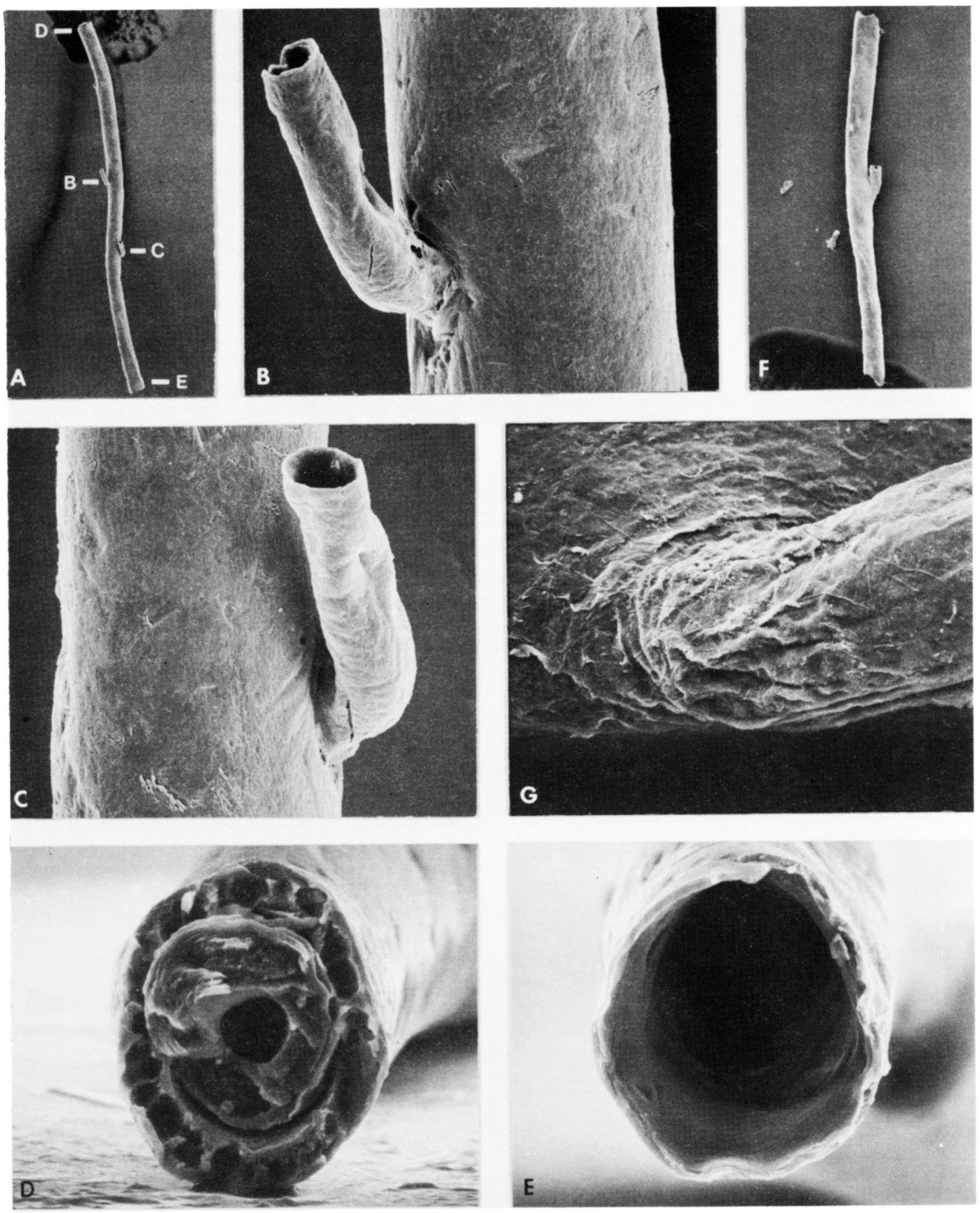

Fig. 2. Chitinous hydroids from Hudson Strait: (A) chitinous hydroid aff. Rhabdohydra sp., hydrosome branch containing three "pendant" thecae. Letters indicate positions of magnified views shown in Figures. 2B-E, GSC No. 101327, 28X; (B) enlarged view of the middle theca of specimen illustrated in 2A showing possible separation of wall layers, $500 \mathrm{X}$; (C) enlarged view of the lowermost theca of specimen illustrated in $2 \mathrm{~A}, 550 \mathrm{X}$; (D) enlarged view of vesicular wall and laminate internal diaphragm with pore, proximal end of hydrosome branch illustrated in 2A, 550X; (E) enlarged view of thin-walled distal end of hydrosome branch illustrated in 2A, 550X; (F) indeterminate chitinous hydroid, GSC No. 101328,60X; (G) enlarged view of the theca of specimen illustrated in 2D showing the wrinkled surface of the attachment area, specimen rotated $90^{\circ}, 1600 \mathrm{X}$. 
G.A. Massey and M.L. Nelson (Amoco Research, Tulsa) for their excellent SEM photomicrography. Amoco Production Company is acknowledged for technical support and permission to publish.

This publication is Geological Survey of Canada Contribution No. 3008.

Chapman, F. and Thomas, D.E. 1936. The Cambrian hydroids of the Heathcote and Monegeeta districts. Proceedings of the Royal Society of Victoria, 48, pp. 193-212.

EIsenack, A. 1932. Neue Mikrofossilien des baltischen Silurs. II. (Foraminiferen, Hydrozoen, Chitinozoen u.a.). Paläontologische Zeitschrift, 14, pp. 257-277.

1934. Neue Mikrofossilien des Silurs. III. und Neue Mikrofossilien des böhemischen Silurs. I. Paläontologische Zeitschrift, 16, pp. 52-76.

1955. Chitinozoen, Hystrichosphären und andere Mikrofossilien aus dem Beyrichia-Kalk. Senckenbergiana Lethaea, 36, pp. 157-188.

1968. Mikrofossilien eines Geschiebes der Borkholmer Stufe baltisches Ordovizium, $F_{2}$. Mitteilungen aus dem Geologischen Staatsinstitut in Hamburg, 37, pp. 81-94.

- 1971. Weitere Mikrofossilien aus dem Beyrichienkalk (Silur). Neues Jahrbuch für Geologie und Paläontologie, Monatshefte, 1971, pp. 449-460.

1976. Mikrofossilien aus dem Vaginatenkalk von Hälludden, Oland. Palaeontographica, Abt. A, 154, pp. 181-203.

- 1977. Mikrofossilien in organischer Substanz aus den Middle Nodular Beds (Wenlock) von Dudley, England. Neues Jahrbuch für Geologie und Paläontologie, Monatshefte, 1977, pp. 25-35.

1978. Mikrofossilien in organischer Substanz aus dem Unteren Wenlock vom Wrens Nest, Dudley, England. Neues Jahrbuch für Geologie und Paläontologie, Monatshefte, 1978, pp. 282-290.

FRYKMAN, P. 1979. Ordovician chitinous hydroids from Peary Land, eastern North Greenland. Rapport Grønlands Geolo- giske Undersøgelse, 91, pp. 25-27.

Hyman, L.H. 1940. The Invertebrates; Protozoa through Ctenophora. McGraw-Hill, New York, 762 p.

KozlowsKI, R. 1959. Les Hydroides Ordovicien à squelette chitineux. Acta Palaeontologica Polonica, 4, pp. 209-271.

Laufeld, S. 1979. "Chitinous" hydroids. In Lower Wenlock faunal and floral dynamics - Vattenfallet section, Gotland. Edited by V. Jaanusson, S. Laufeld and R. Skoglund. Sveriges Geologiska Undersökning, Serie C, no. 762, pp. 77-78.

Ma clean, B., Williams, G.L., Sanford, B.V., Klassen, R.A., Blakeney, C., and Jennings, A. 1986. A reconnaissance study of the bedrock and surficial geology of Hudson Strait, N.W.T. Geological Survey of Canada, Paper 86-1B, pp. 617 635.

McGregor, D.C. and Narbonne, G.M. 1978. Upper Silurian trilete spores and other microfossils from the Read Bay Formation, Cornwallis Island, Canadian Arctic. Canadian Journal of Earth Sciences, 15, pp. 1292-1303.

Miller, M.A. 1976. Maysvillian (Upper Ordovician) chitinozoans from the Cincinnati Region of Ohio, Indiana and Kentucky. Unpublished Master's thesis, Ohio State University, $251 \mathrm{p}$.

Miller, M.A. and Williams, G.L. 1987. The essential role of palynology for bedrock mapping in Hudson Strait, N.W.T. 20th Annual Meeting, American Association of Stratigraphic Palynologists, Programme and Abstracts, p. 116.

1988. Velatasphaera hudsonii gen. et sp. nov., an Ordovician acritarch from Hudson Strait, Northwest Territories, Canada. Palynology, 12, pp. 121-127.

Quilty, P.G. 1971. Cambrian and Ordovician dendroids and hydroids of Tasmania. Journal of the Geological Society of Australia, 17, pp. 171-189.

Skevington, D. 1965. Chitinous hydroids from the Ontikan limestones (Ordovician) of Oland, Sweden. Geologiska Föreningens i Stockholm Förhandlingar, 87, pp. 152-162.

Tauoourdeau, P. 1965. Chitinozoaires de l'Ordovicien des U.S.A.; comparaison avec les faunes de l'ancien monde. Revue de l'Institut Français du Pétrole, 20, pp. 463-485. 